\title{
Highly active and stable porous polymer heterogenous catalysts for decomposition of formic acid to produce $\mathrm{H}_{2}$
}

\author{
Yan Zhang a,b, Yuan Lyu a,\#, Yuqing Wang a,b, Cunyao Li a , Miao Jiang a, Yunjie Ding a,c,* \\ a Dalian National Laboratory for Clean Energy, Dalian Institute of Chemical Physics, Chinese Academy of Sciences, Dalian 116023, Liaoning, China \\ b University of Chinese Academy of Sciences, Beijing 100049, China \\ c State Key Laboratory of Catalysis, Dalian Institute of Chemical Physics, Chinese Academy of Sciences, Dalian 116023, Liaoning, China
}

\section{A R T I C L E I N F 0}

\section{Article history:}

Received 8 October 2018

Accepted 9 December 2018

Published 5 February 2019

\section{Keywords:}

Heterogeneous

Porous organic polymer

Formic acid

Decomposition

Hydrogen

\begin{abstract}
A B S T R A C T
Formic acid (FA) has attracted extensive attention as a hydrogen storage material. Here, we develop two heterogeneous catalysts based on porous organic polymers (POPs). After loading the Ru species, the catalyst bearing the triphenylphosphine ligand showed excellent performance in terms of activity and stability for the decomposition of FA to produce hydrogen.
\end{abstract}

(C) 2019, Dalian Institute of Chemical Physics, Chinese Academy of Sciences. Published by Elsevier B.V. All rights reserved.
Formic acid (FA) has attracted tremendous attention as it can be catalytically decomposed into hydrogen and carbon dioxide. Besides, FA exhibits several advantages such as easy storage and transportation, nontoxicity, and high volumetric hydrogen density (53 g/L), which makes it a potential carrier for the production and storage of hydrogen [1-4]. Thus, various homogeneous and heterogeneous catalysts for the decomposition of FA have been developed [5-7]. Transition-metal complexes with phosphorus and nitrogen donor ligands typically exhibit superior catalytic performance [8-16]; however, difficulties in catalyst separation hinder their applications. Heterogeneous catalysts have advantages due to the facile separation and recycling, but their activity and selectivity have not reached the level of homogeneous catalysts [17-19]. To solve this problem, metal complexes immobilized on silicas and polymers have been researched, and good performance obtained [20-23]. More recently, conjugated microporous polymers (CMP) prepared via a coupling reaction have been used as a support for the deployment of FA decomposition catalysts $[24,25]$. Generally, due to the low surface areas, diffusion limitation remains a drawback for CMP. However, porous organic polymers (POPs), synthesized by solvothermal polymerization of vinyl-functionalized ligands, have highly porous structures and high surface areas, and have emerged as an ideal platform for the deployment of catalysts [26,27]. In this regard, we synthesized two POPs, POPs-PPh 3 and POPs-TPP, from organic ligands bearing phosphorous and nitrogen donors, respectively (Scheme 1). After polymerizing and treating with Ru species as the precursor, the catalysts were tested for their effectiveness in the decomposition of FA.

\footnotetext{
* Corresponding author. Tel/Fax: +86-411-84379143; E-mail: dyj@dicp.ac.cn

\# Corresponding author. Tel: +86-411-84379601; Fax: +86-411-84379143; E-mail: luyuan@dicp.ac.cn

This work was supported by the National Key R\&D Program of China (2017YFB0602203, 2017YFB0602501), and the Strategic Priority Research Program of the Chinese Academy of Sciences (XDA21020300, XDB17020400).

DOI: S1872-2067(19)63275-4 | http://www.sciencedirect.com/science/journal/18722067 | Chin. J. Catal., Vol. 40, No. 2, February 2019
} 

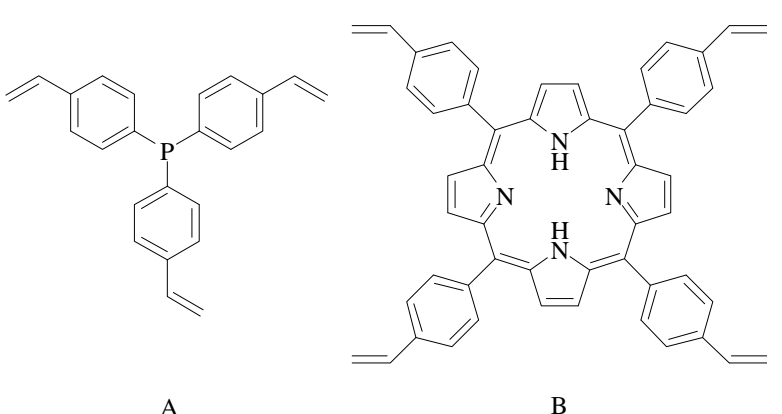

B

Scheme 1. (A) Tris(4-vinylphenyl)phosphine $\left(\mathrm{PPh}_{3}\right)$ and (B) tetra(4-vinylphenyl) porphyrin (TPP).

POPs- $\mathrm{PPh}_{3}$ and POPs-TPP were prepared according to the methods reported previously $[27,28]$. After metalation of $\mathrm{Ru}$, the catalysts were characterized by solid-state ${ }^{13} \mathrm{C}$ and ${ }^{31} \mathrm{P}$ MAS NMR, $\mathrm{N}_{2}$ physical adsorption, thermogravimetric analysis, and in situ FT-IR. The ${ }^{13} \mathrm{C}$ MAS NMR spectra of Ru@POPs-PPh 3 and Ru@POPs-TPP (Fig. 1a) show broad peaks from 20 to 50 ppm, which were attributed to the polymerized vinyl group. The broad peaks from 120 to 150 ppm of Ru@POPs-PPh 3 are assigned to the aromatic carbons, while the broad peaks from 110 to 150 ppm of Ru@POPs-TPP are assigned to the tetraphenylporphyrin group. The ${ }^{31} \mathrm{P}$ MAS NMR spectrum of
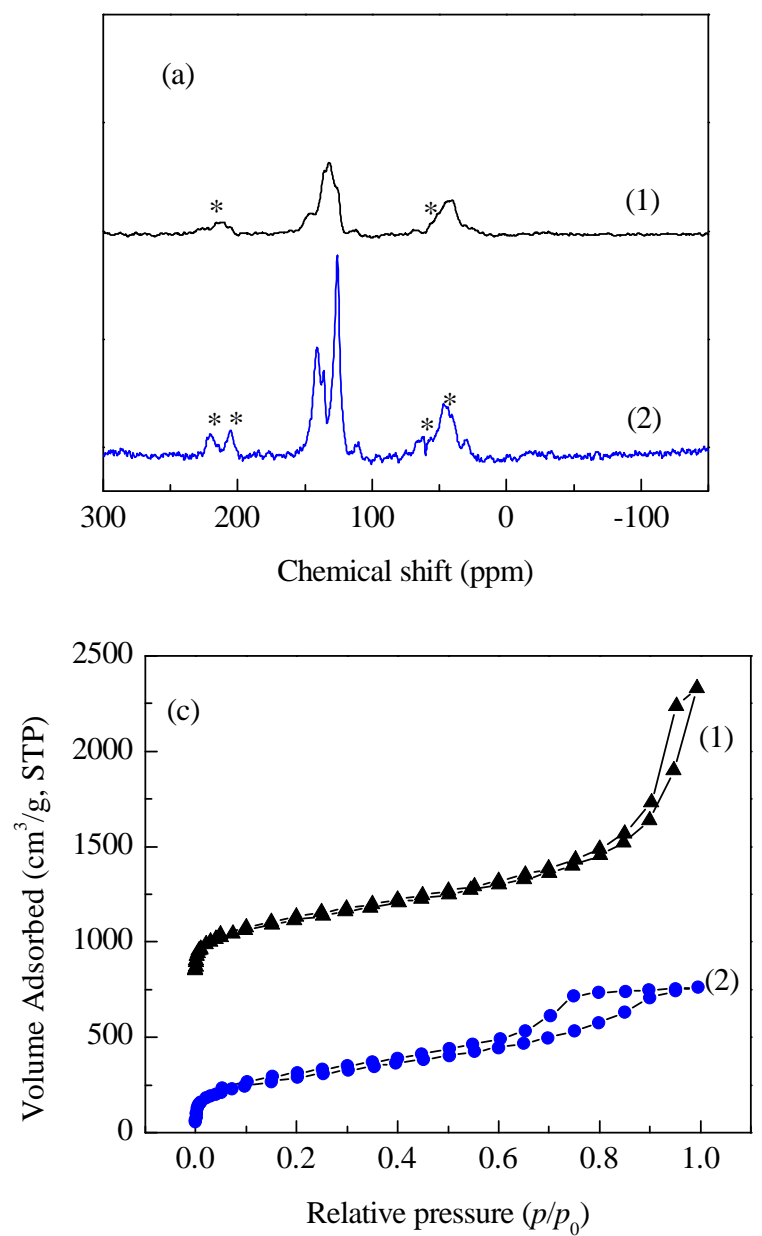

Ru@POPs- $\mathrm{PPh}_{3}$ (Fig. 1b) shows a single peak at $-6.9 \mathrm{ppm}$, which is consistent with the uncoordinated $\mathrm{P}$ species. The peaks at $24.4 \mathrm{ppm}$ are assigned to the $\mathrm{P}$ species coordinated with the $\mathrm{Ru}$ species and the oxidation state of phosphorous $(\mathrm{P}=0)$ [29]. $\mathrm{N}_{2}$ sorption isotherms of $\mathrm{Ru} @ \mathrm{POPs}-\mathrm{PPh}_{3}$ and Ru@POPs-TPP (Fig. 1c) showed that both catalysts show typical type I and type IV curves. The steep increase at relative pressures below 0.01 is due to the filling of the micropores, while the hysteresis loops are due to the mesopores. The pore size distribution curves (Fig. S1 in Supporting Information), calculated by a nonlocal density functional theory method (NLDFT), also confirm that abundant micropores and mesopores were present in these catalysts. The BET surface areas of Ru@POPs-PPh 3 and Ru@POPs-TPP are 1152 and 1045 m²/g, respectively. A high BET surface area is a typical characteristic of POP materials, which is favorable for the dispersion of active components and mass transfer in reactions. Thermogravimetric analysis (TGA) of Ru@POPs-PPh 3 and Ru@POPs-TPP (Fig. S2) shows that the decomposition temperature of these catalysts was higher than $400{ }^{\circ} \mathrm{C}$, which indicates their excellent thermal stability. The exact Ru content of the polymer catalysts is measured by inductively coupled plasma-optical emission spectrometry (ICP-OES) (Table S1). In situ FT-IR spectroscopy analysis, employing $\mathrm{CO}$ as a probe molecule, was carried out to
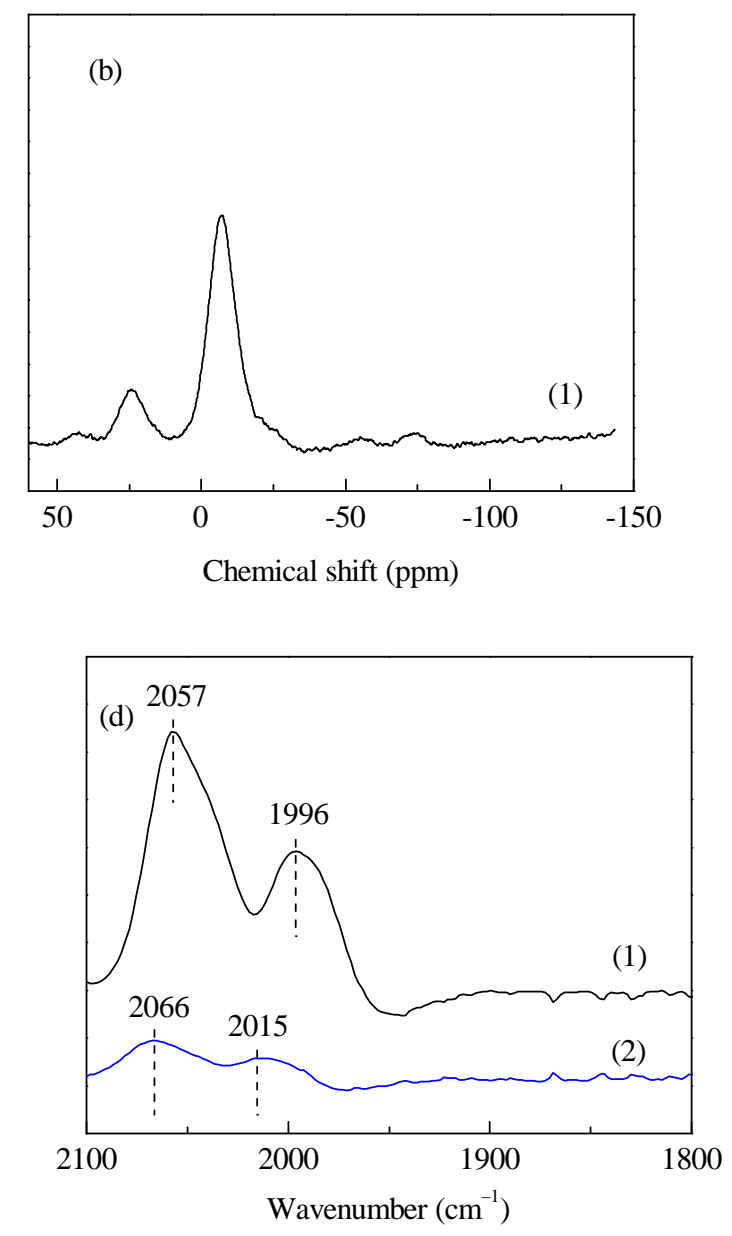

Fig. 1. (a) ${ }^{13} \mathrm{C}$ CP/MAS NMR spectra, (b) ${ }^{31} \mathrm{P}$ MAS NMR spectrum, (c) $\mathrm{N}_{2}$ isotherms, and (d) in situ FT-IR spectra of (1) Ru@POPs-PPh 3 and (2) Ru@POPs-TPP. 
compare the states of coordinated Ru sites on Ru@POPs- $\mathrm{PPh}_{3}$ and Ru@POPs-TPP (Fig. 1d). The results reveal that the two absorption peaks of Ru@POPs-PPh 3 at 2057 and $1996 \mathrm{~cm}^{-1}$ can be attributed to CO bound to Ru (II), while Ru@POPs-TPP shows peaks at 2066 and $2015 \mathrm{~cm}^{-1}$ [30]. The difference in wavenumbers between Ru@POPs-TPP and Ru@POPs-PPh indicates that the different types of ligands in the polymer framework affect the energy state of $\mathrm{CO}$ bound to $\mathrm{Ru}$; this is assumed to be closely related to the electron density of $\mathrm{Ru}$, and further affects the performance of the catalysts during the decomposition of FA.

Subsequently, we investigated the decomposition of FA on different catalysts at $140{ }^{\circ} \mathrm{C}$ (Table 1 ). The results showed that $\left[\mathrm{RuCl}_{2}\left(\mathrm{PPh}_{3}\right)_{3}\right]_{2}$ exhibited very high initial activity with a maximum TOF of $11177 \mathrm{~h}^{-1}$, but this performance did not last because of deactivation. The pre-catalyst, $\left[\mathrm{RuCl}_{2} \text { (p-cymene) }\right]_{2}$, was also tested and a TOF of $3912 \mathrm{~h}^{-1}$ was obtained. This result is not remarkable compared to numerous other homogeneous catalysts. As expected, the support material, $\mathrm{POPs}-\mathrm{PPh}_{3}$ without $\mathrm{Ru}$, showed no activity. After being loaded with $\mathrm{Ru}$, the $\mathrm{Ru} @ P O P s-\mathrm{PPh}_{3}$ catalyst was able to achieve near-full conversion with a maximum TOF of $7284 \mathrm{~h}^{-1}$. Analysis of the gas phase showed high $\mathrm{H}_{2}$ selectivity with about $0.1 \% \mathrm{CO}$. The other polymer, POPs-TPP loaded with Ru, was also tested. Unfortunately, Ru@POPs-TPP showed low activity $\left(2308 \mathrm{~h}^{-1}\right)$ and the CO content of the gas phase was much higher $(2.221 \%)$. There was no significant difference in the surface areas between Ru@POPs-PPh 3 and Ru@POPs-TPP, but the performance with regard to FA decomposition was different. The results show that the properties of the ligands in the polymer framework could significantly impact the activity and selectivity of the Ru@POPs catalysts. Subsequently, a hot filtration test was conducted. The reaction stopped when the catalysts were removed from the hot reaction mixture and restarted when the used catalysts were added again into the hot reaction mixture (Table S2). These results confirm the heterogeneous nature of the catalytic process. To confirm the state of the Ru species in our heterogeneous catalysts, transmission electron microscopy (TEM) was used to observe the fresh and used catalysts. The TEM images (Fig. 2 and Fig. S3) show that Ru nanoparticles cannot be detected in the fresh Ru@POPs- $\mathrm{PPh}_{3}$ and $\mathrm{Ru} @ P O P s-T P P$ catalysts, which demonstrates that the Ru was

\section{Table 1}

Decomposition of FA by different catalysts.

\begin{tabular}{|c|c|c|c|c|c|c|}
\hline Entry & Catalyst & Substrate & $\begin{array}{c}T \\
\left({ }^{\circ} \mathrm{C}\right)\end{array}$ & $\begin{array}{l}\text { TOF } \\
\left(h^{-1}\right)\end{array}$ & $\begin{array}{c}\text { Conv. } \\
(\%)\end{array}$ & $\begin{array}{c}\mathrm{CO} \\
(\%)\end{array}$ \\
\hline $1^{\mathrm{a}}$ & $\mathrm{RuCl}_{2}\left(\mathrm{PPh}_{3}\right)_{3}$ & FA & 140 & $11177^{b}$ & 28 & 0.026 \\
\hline $2^{c}$ & {$\left[\mathrm{RuCl}_{2}(\mathrm{p} \text {-cymene })\right]_{2}$} & FA & 140 & 3912 & $>99$ & 0.069 \\
\hline 3 & POPs-PPh & FA & 140 & 0 & 0 & - \\
\hline 4 & Ru@POPs-PPh 3 & FA & 140 & 7284 & $>99$ & 0.135 \\
\hline $5^{d}$ & Ru@POPs-TPP & FA & 140 & 2308 & 76.2 & 2.221 \\
\hline 6 & $\mathrm{Ru} @ P O P s-\mathrm{PPh}_{3}$ & $\mathrm{FA}+\mathrm{TEA} \mathrm{e}^{\mathrm{e}}$ & 140 & 55855 & $>99$ & 0.036 \\
\hline 7 & Ru@POPs-PPh 3 & $\mathrm{FA}+\mathrm{TEA} \mathrm{e}^{\mathrm{e}}$ & 150 & 63778 & $>99$ & 0.038 \\
\hline 8 & $\mathrm{Ru} @ P O P s-P_{3} h_{3}$ & $\mathrm{FA}+\mathrm{TEA} \mathrm{e}^{\mathrm{e}}$ & 130 & 24322 & $>99$ & 0.018 \\
\hline
\end{tabular}

Reaction conditions: 0.46 g FA, 5 mL DMF, 20 mg catalysts, atmospheric pressure; a $0.01 \mathrm{mmol} \mathrm{RuCl}_{2}\left(\mathrm{PPh}_{3}\right)_{3}, 1.5 \mathrm{~min}$; ${ }^{\text {b }} \mathrm{TOF} 3914 \mathrm{~h}^{-1}$ in $5 \mathrm{~min}$; c $0.01 \mathrm{mmol}\left[\mathrm{RuCl}_{2}(\mathrm{p} \text {-cymene) }]_{2}\right.$; d $100 \mathrm{~min}$; e $0.48 \mathrm{~g}$ TEA was added $(F A: T E A=5: 2)$.

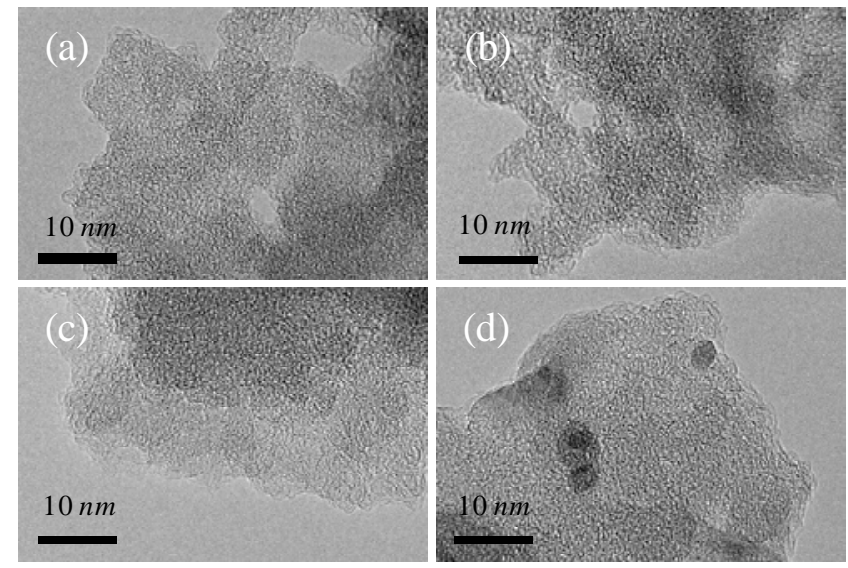

Fig. 2. The TEM images. (a) Fresh Ru@POPs-PPh; (b) Used Ru@POPs-PPh ; (c) Fresh Ru@POPs-TPP; (d) Used Ru@POPs-TPP.

highly dispersed. After the reaction, $\mathrm{Ru}$ nanoparticles were visible on the Ru@POPs-TPP catalyst but still were not able to be detected in used Ru@POPs- $\mathrm{PPh}_{3}$; this demonstrates that the $\mathrm{Ru} @ \mathrm{POPs}-\mathrm{PPh}_{3}$ has excellent stability.

The catalytic activity can be improved with the presence of bases, according to previous research [31]. Therefore, a mixture of FA and triethylamine (TEA) was chosen as a model substrate to investigate the effect of bases on the reaction. The results showed that the activity of Ru@POPs- $\mathrm{PPh}_{3}$ was remarkably increased when a certain amount of TEA was added (Table 1, Entry 6). The experiment resulted in a complete conversion, with a TOF of $55855 \mathrm{~h}^{-1}$ at $140{ }^{\circ} \mathrm{C}$ and at atmospheric pressure. The influence of temperature on the reaction was investigated. A high TOF of $63778 \mathrm{~h}^{-1}$ was obtained at $150{ }^{\circ} \mathrm{C}$ and a TOF of $24322 \mathrm{~h}^{-1}$ was obtained at $130{ }^{\circ} \mathrm{C}$ (Table 1, Entries 7 and 8). To the best of our knowledge, the Ru@POPs-PPh 3 catalyst displayed higher activity than most heterogeneous catalysts. This excellent performance demonstrates that $\mathrm{Ru} @ P O P s-\mathrm{PPh}_{3}$ exhibits high activity that is similar to homogeneous catalysts [31].

A mixture of FA and TEA was chosen as the substrate to study the reusability of the Ru@POPs- $\mathrm{PPh}_{3}$ catalyst (Table 2). The catalyst could be reused at least five times without loss of activity, indicating performance superior to that of conventional polymer catalysts [21]. ICP analysis of the filtered reaction solutions showed that the leaching of Ru was low. The excellent stability of the catalyst could be attributed to the high BET surface areas and the high P concentration around the Ru species.

Table 2

Recycling study of the Ru@POPs-PPh 3 catalyst.

\begin{tabular}{lccc}
\hline Run & TOF $\left(\mathrm{h}^{-1}\right)$ & CO $(\%)$ & Ru loss ${ }^{\text {a }}\left(10^{-6}\right)$ \\
\hline 1 & 44560 & 0.171 & 0.39 \\
2 & 46010 & 0.114 & 0.44 \\
3 & 39655 & 0.245 & 0.63 \\
4 & 38784 & 0.696 & 0.27 \\
5 & 38526 & 0.628 & 0.29 \\
\hline
\end{tabular}

Reaction conditions: 0.46 g FA, 0.40 g TEA, $5 \mathrm{~mL} \mathrm{DMF,} 50 \mathrm{mg}$ $\mathrm{Ru} @ \mathrm{POPs}-\mathrm{PPh}_{3}$ catalyst, $140{ }^{\circ} \mathrm{C}$, atmospheric pressure. ${ }^{a}$ Ru contents of the filtered reaction solution. 


\section{Graphical Abstract}

Chin. J. Catal., 2019, 40: 147-151 doi: S1872-2067(19)63275-4

Highly active and stable porous polymer heterogenous catalysts for decomposition of formic acid to produce $\mathrm{H}_{2}$

Yan Zhang, Yuan Lyu*, Yuqing Wang, Cunyao Li, Miao Jiang, Yunjie Ding* Dalian Institute of Chemical Physics, Chinese Academy of Sciences; University of Chinese Academy of Sciences

Two heterogeneous Ru@POPs catalysts were synthesized for the decomposition of formic acid, and excellent performance was obtained. The properties of the ligands in the polymer framework significantly impact the activity and selectivity of the catalysts.

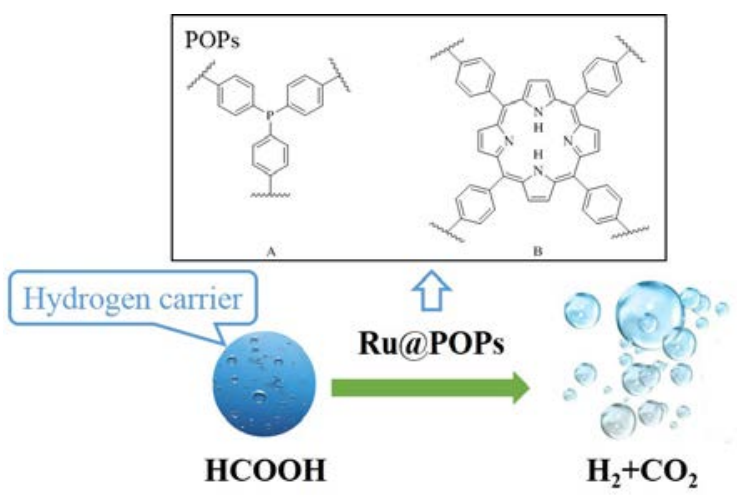

827-834.

[13] Y. Himeda, Green Chem., 2009, 11, 2018-2022.

[14] S. M. Lu, Z. J. Wang, J. J. Wang, J. Li, C. Li, Green Chem., 2018, 20 , 1835-1840.

[15] A. Boddien, B. Loges, F. Gartner, C. Torborg, K. Fumino, H. Junge, R. Ludwig, M. Beller, J. Am. Chem. Soc., 2010, 132, 8924-8934.

[16] A. Boddien, D. Mellmann, F. Gaertner, R. Jackstell, H. Junge, P. J. Dyson, G. Laurenczy, R. Ludwig, M. Beller, Science, 2011, 333, 1733-1736.

[17] F. N. Wang, J. M. Xu, X. Z. Shao, X. Su, Y. Q. Huang, T. Zhang, ChemSusChem, 2016, 9, 246-251.

[18] Q. G. Liu, X. F. Yang, Y. Q. Huang, S. T. Xu, X. Su, X. L. Pan, J. M. Xu, A. Q. Wang, C. H. Liang, X. K. Wang, T. Zhang, Energy Environ. Sci., 2015, 8, 3204-3207.

[19] Q. Y. Bi, X. L. Du, Y. M. Liu, Y. Cao, H. Y. He, K. N. Fan, J. Am. Chem. Soc., 2012, 134, 8926-8933.

[20] W. J. Gan, P. J. Dyson, G. Laurenczy, ChemCatChem, 2013, 5, 3124-3130.

[21] W. J. Gan, P. J. Dyson, G. Laurenczy, React. Kinet. Catal. Lett., 2009, 98, 205-213.

[22] H. Hu, Q. Q. Yan, R. L. Ge, Y. A. Gao, Chin. J. Catal., 2018, 39, 1167-1179.

[23] Y. F. Wang, Y. M. Fan, J. Jian, Y. M. Pan, L. Zhao, X. P. Jing, S. J. Zhou, X. H. Chen, Q. Du, L. Wang, X. J. Wu, X. K. Fu, Acta Chim. Sin., 2017, $75,715-722$.

[24] C. Broicher, S. R. Foit, M. Rose, P. J. C. Hausoul, R. Palkovits, ACS Catal., 2017, 7, 8413-8419.

[25] P. J. C. Hausoul, C. Broicher, R. Vegliante, C. Gob, R. Palkovits, Angew. Chem. Int. Ed., 2016, 55, 5597-5601.

[26] T. Wang, W. L. Wang, Y. Lyu, K. Xiong, C. Y. Li, H. Zhang, Z. P. Zhan, Z. Jiang, Y. J. Ding, Chin. J. Catal., 2017, 38, 691-698.

[27] Q. Sun, M. Jiang, Z. Shen, Y. Jin, S. Pan, L. Wang, X. Meng, W. Chen, Y. Ding, J. Li, F. S. Xiao, Chem. Commun., 2014, 50, 11844-11847.

[28] Z. F. Dai, Q. Sun, X. L. Liu, C. Q. Bian, Q. M. Wu, S. X. Pan, L. Wang, X. J. Meng, F. Deng, F. S. Xiao, J. Catal., 2016, 338, 202-209.

[29] X. K. Chen, H. J. Zhu, X. G. Song, H. Du, T. Wang, Z. Zhao, Y. J. Ding, React. Kinet. Mech. Catal., 2017, 120, 637-649.

[30] C. Kubis, I. Profir, I. Fleischer, W. Baumann, D. Selent, C. Fischer, A. Spannenberg, R. Ludwig, D. Hess, R. Franke, A. Borner, Chem.-Eur. J., 2016, 22, 2746-2757. 


\section{多孔聚合物催化剂高效催化甲酸分解制氢

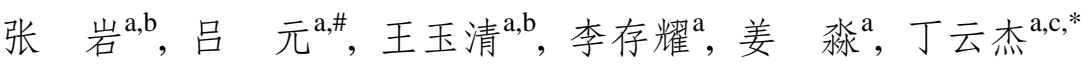 \\ a国科学院大连化学物理研究所洁净能源国家实验室(筹), 辽宁大连 116023 \\ b 中国科学院大学, 北京100049 \\ c中国科学院大连化学物理研究所催化基础国家重点实验室, 辽宁大连116023}

摘要: 氢能作为一种新型能源被认为是未来最理想的二次能源, 与传统能源相比, 具有能量密度高、热效率高、零污染的 特点. 然而, 通常状态下氢能以低密度的气体形式存在, 易燃易爆, 给储存和运输带来诸多困难. 因此, 研发出安全高效的 储氢方法尤为重要. 甲酸在室温下为液体, 无毒, 挥发性低, 方便储存和运输; 而且甲酸的体积储氢量高达 $53 \mathrm{~g} / \mathrm{L}$, 并能够通 过催化甲酸分解反应释放出氢气和催化二氧化碳加氢反应将氢气转化成甲酸, 因而甲酸被认为是理想的氢能载体. 对于 甲酸分解反应, 制备出高活性的催化剂是关键, 常用的催化剂包括均相催化剂和多相催化剂两类. 均相催化剂主要是有机 膦、有机胺等有机配体与金属离子 $(\mathrm{Ru} 、 \mathrm{Ir} 、 \mathrm{Rh} 、 \mathrm{Fe}$ 等)配位得到的配合物, 多相催化剂主要是多孔材料(活性炭、分子篎、 二氧化硅等)负载的 $\mathrm{Au} 、 \mathrm{Pd} 、 \mathrm{Pt}$ 等单金属或其合金. 均相催化剂具有高活性、高选择性的优点, 而多相催化剂易于分离. 为 了结合均相催化剂和多相催化剂的优点, 本文基于均相催化剂和多孔聚合物材料的发展, 将均相催化剂针定在多孔有机聚 合物载体上, 制备出Ru@POPs-PPh 3 及Ru@POPs-TPP催化剂.

首先, 对制备的催化剂进行了一系列表征. 通过 ${ }^{13} \mathrm{C}$ 和 ${ }^{31} \mathrm{P}$ 固体核磁谱图证实了催化剂的结构; 热重分析结果显示催化 剂的分解温度高于 $400{ }^{\circ} \mathrm{C}$, 表明此催化剂具有优良的热稳定性; $\mathrm{N}_{2}$ 物理吸附结果表明该催化剂具有非常高的比表面积和丰 富的孔道结构; 原位一氧化碳吸附红外光谱结果表明聚合物配体对中心金属离子的电子态具有重要影响. 随后, 对制备的 催化剂进行了活性评价实验. 结果显示, Ru@POPs- $\mathrm{PPh}_{3}$ 及Ru@POPs-TPP催化剂均能催化甲酸分解脱氢, 并通过热过滤实 验证明催化过程是多相催化过程. 使用前后催化剂的透射电子显微镜表征显示, 使用前Ru@POPs- $\mathrm{PPh}_{3}$ 及Ru@POPs-TPP催 化剂上均未发现Ru纳米粒子, 在使用后的Ru@POPs-TPP催化剂上发现了 Ru纳米颗粒, 而Ru@POPs- $\mathrm{PPh}_{3}$ 上的Ru仍然是高 分散状态, 没有团聚成纳米颗粒, 表明Ru@POPs-PPh ${ }_{3}$ 具有更高的稳定性. 对 Ru@POPs- $\mathrm{PPh}_{3}$ 催化剂的进一步研究发现, 在 三乙胺参与下, $140{ }^{\circ} \mathrm{C}$ 条件下, 其催化甲酸分解脱氢的TOF值可达 $55855 \mathrm{~h}^{-1}$, 该催化活性可与均相催化剂相媲美; 稳定性实 验结果表明该催化剂具有非常高的稳定性, 能够连续使用5次而活性没有明显降低. 催化剂的高活性和稳定性归因于特定 的聚合物配体, 以及载体的高比表面积和高的膦配体浓度. 本工作可为甲酸分解催化剂的设计提供带来启发.

关键词: 多相催化; 多孔聚合物; 甲酸; 分解; 氢能

收稿日期: 2018-10-08. 接受日期: 2018-12-09. 出版日期: 2019-02-05.

*通讯联系人. 电话/传真: (0411)84379143; 电子信箱: dyj@dicp.ac.cn

\#通讯联系人. 电话: (0411)84379601; 传真: (0411)84379143; 电子信箱: luyuan@dicp.ac.cn

基金来源：国家重点研发计划(2017YFB0602203, 2017YFB0602501); 中国科学院战略性先导科技专项(XDA21020300, XDB17020400).

本文的电子版全文由Elsevier出版社在ScienceDirect上出版(http://www.sciencedirect.com/science/journal/18722067). 